\title{
A study on carbon sequestration in natural for ests of India
}

\author{
PoonamK hurana \\ Department of Applied Science and Humanities, J. P. Institute of Engineering \& Technology, P.O. Rajpura, Mawana \\ Road, Meerut-250 001 (U. P.), INDIA \\ E-mail:punnu.k@gmail.com
}

\begin{abstract}
Among the global common concerns, climate change has been identified as the most important environmental challenge faced by human beings. Emission of carbon dioxide, methane, nitrous oxide, chlorofluorocarbons and hydrocarbons are identified as green house gases causing warming of earth globally. Of these gases, $\mathrm{CO}_{2}$ alone accounts for 60 percent share. The most practical way of removing excess carbon from atmosphere and storing it in to a biological system is by absorption of atmospheric $\mathrm{CO}_{2}$ into the physiological system, plant biomass and finally into the soil . Carbon is thus sequestered into the plants and then the animals. Studies have established that Carbon sequestration by trees and forest could provide relatively low cost net emission reduction. Carbon management in forest is therefore one of the most important agenda in India in $21^{\text {st }}$ century in context of green house gases effect and mitigation of global climate changes. Studies indicated that Indian forests share 1,083.81 MtC in the year 1994 to 3,907.67 MtC in the year 1993. Estimated rate of Carbon flux in selected Indian planted forest reveals that planted forests of short rotation tree species with regular leaf shedding patterns have more capacity for carbon sequestering in litter which decomposes more rapidly than those with annual or bimodal leaf shedding patterns. Mixed planted forest of exotic and native species could be more efficient in sequestering Carbon than the monocultures. This contribution reviews Carbon sequestration in Indian forests at national level and site-specific situations;and elaborates some possible opportunities for sustainable Carbon forestry.
\end{abstract}

Keywords: Carbon sequestration, Climate change, Forests, Green house gases

\section{INTRODUCTION}

With the growing danger of environmental pollution, energy crisis, loss of biological diversity and mismanagement of natural resources due to economic development needs of human civilization, the role of natural as well as planted forests is being increasingly felt for diverse intangible ecosystems services than the tangible economic goods. Consequently the dimensions of forest-based trades and international politics are shifting from timber-oriented focus toward the regional and global services like conservation of biological diversity, watershed values, ecotourism and mitigating climate changes (Katila and Puustjarvi, 2004). Global forest conservation; afforestation and reforestation especially in the tropics; for carbon fixation is the supreme concern of environment and forestry managers. This attempts promote research on carbon sequestration by natural and planted forest in India and suggests opportunities for further research and development for sustainable carbon storage-oriented multifunctional forestry.

\section{THE CLIMATE CHANGE SCENARIO IN INDIA}

Among the common global concerns, climate change has been identified as the most important environmental challenge in front of humanity with wide implications for food production, natural ecosystems, fresh water supply and health etc. Growing population, rapid industrialization and urbanization coupled with Climate Change will create additional pressures on India's overall ecology and socio-economic system. Some important points regarding the climate change scenario in India are:

The Intergovernmental Panel on Climate Change, in its 2007 report, predicts that temperatures will rise by $2.7-$ $4.3^{\circ} \mathrm{C}$ over India by the $2080 \mathrm{~s}$.

The panel also predicated an increase in rainfall over the Indian sub-continent by 6-8 percent and that the sea level would rise by 88 centimetres by 2100 .

An annual mean surface temperature rise by the end of this century, ranging from $3^{\circ} \mathrm{C}$ to $5^{\circ} \mathrm{C}$ (under A2 IPCC scenario) and $2.5^{\circ} \mathrm{C}$ to $4^{\circ} \mathrm{C}$ (under B2 IPCC scenario), with the warming more pronounced in the northern parts of India.

A 20 percent rise in all India summer monsoon rainfall and a further rise in rainfall is projected over all except Punjab, Rajasthan, and Tamil Nadu, which show a slight decrease. 
Extreme rise in maximum and minimum temperatures is also expected and similarly extreme precipitation is also projected, particularly over the West Coast of India and West Central India.

Observations over India show that the mean annual surface air temperature has increased by $0.4-0.6^{\circ} \mathrm{C}$ in the last 100 years.

The warming may be more pronounced in the northern parts of India. Extremes in maximum and minimum temperatures are also expected to increase.

It is projected that on an average there will be a 20 per cent rise in all India summer monsoon rainfall over all states except Punjab and Rajasthan in the North West and Tamil Nadu in the South, which show a slight decrease.

As regards the extreme rainfall events, an overall increase in the rainy day intensity by $1-4 \mathrm{~mm} /$ day may occur in most areas in India, except for small areas in northwest India where the rainfall intensities may decrease by 1 $\mathrm{mm} /$ day.

Using the climate model, it is projected that there will be an overall decrease in the number of rainy days over major parts of India. This decrease may be more pronounced in the western and central parts of India (by more than 15 days) while near foothills of Himalayas (Uttaranchal) and in northeast India the number of rainy days may increase by 5-10 days.

\section{REMOVAL OF EXCESS ATMOSPHERIC CARBON}

Carbon sequestration is the process through which agricultural and forestry practices remove carbon dioxide $\left(\mathrm{CO}_{2}\right)$ from the atmosphere. The term "sinks" is also used to describe agricultural and forestry lands that absorb $\mathrm{CO}_{2}$, the most important global warming gas emitted by human activities. Agricultural and forestry practices can also release $\mathrm{CO}_{2}$ and other greenhouse gases to the atmosphere.

Sequestration activities can help prevent global climate change by enhancing carbon storage in trees and soils, preserving existing tree and soil carbon, and by reducing emissions of $\mathrm{CO}_{2}$, methane $\left(\mathrm{CH}_{4}\right)$ and nitrous oxide $\left(\mathrm{N}_{2} \mathrm{O}\right)$. Thus carbon can be sequestered biologically in the forest ecosystem first into the plants and then to the animals. Carbon sequestration in forests occurs in living biomass of above ground and soil (Table 1).

Through sustainable forest management regimes, the rate of Carbon sequestration could be enhanced upto $1.6 \mathrm{pg}$ C/yr by the year 2010. Chaturvedi (1994) estimated that in Indian forests, one tonne of carbon could be sequestered by $2.2 \mathrm{t}$ of wood. Studies have established that carbon sequestration by trees could provide relatively net emission reductions (Callaway and McCarl, 1996, Stavins, 1999). Carbon management in forests therefore is one of the most important agenda in India in $21^{\text {st }}$ century in context of green house gas effect and mitigation of global climate changes. Forest ecosystems need longest response time to adapt through migration and re-growth (Leemans and Eickhout, 2004). A long gestation period is involved in developing and implementing adaptation strategies in forestry sector (Ravindranath and Sathaye, 2002). Thus there is need to develop and implement adaptation strategies. Some of the no regret policies and forest management practices are: incorporating climate concerns in long term forest policy making process, conservation of forest and reducing forest fragmentation, expansion of protected areas and linking them.

\section{CARBON SEQUESTRATION BY INDIAN FORESTS}

National assessments: Manhas et al. (2006) assessed total carbon stored by Indian forests as $11085.16 \mathrm{Mt}$ and 1083.81 Mt for the year 1984 and 1994, respectively. The order of carbon contribution stocked for the major forests is: miscellaneous forest> shorea robusta forest> Tectona grandis forests> temperate forests> tropical forests $>$ Bamboo forest, etc. The values predicted by different authors range from 1,083.81 Mt C (Manhas et al., 2006) for the year 1984 to 3,907.67 MtC (Chhabra et al., 2002) for the year 1994 (Table 1). Estimated rate of Carbon flux in selected planted forests in India (Table 2) (Raizada et al., 2003) revealed that-i) Planted forests of short rotation tree species with regular leaf shedding patterns have more capacity for $\mathrm{C}$ sequestering in litter, ii) Fast growing conifers may produce slow decomposing litter leading to accumulation on forest floor,hence risk for fire damage and decline in ground flora diversity, iii) Mixed planted forests of exotic and native species could be more efficient in sequestering $\mathrm{C}$ than monocultures and fast growing hardy species like Eucalyptus would be ideal choice for wasteland afforestation.

Soil $\mathrm{C}$ is important part of terrestrial $\mathrm{C}$ pool. Its size has been estimated between 700 to $3,000 \mathrm{Gt} C$ as organic $\mathrm{C}$ and 780 to $930 \mathrm{Gt} \mathrm{C}$ as Calcium carbonate $\left(\mathrm{CaCO}_{3}\right)$ Other $\mathrm{C}$ pools are the oceans $(38,000 \mathrm{Gt} \mathrm{C})$ fossils $\mathrm{C}$ reserves $(6,000 \mathrm{Gt} \mathrm{c}) \mathrm{CO}_{2}$ in atmosphere $(720 \mathrm{Gt} \mathrm{c})$ and Biomass of plants (560 to $835 \mathrm{Gt} \mathrm{C}$ ) (Bouwman, 1990). In the soil under tropical rain forests this pool is almost equal to that of above ground Biomass (Sombroek et al., 1993). Region wise soil organic carbon store is estimated maximum in central peninsular region $(3,656.70 \mathrm{Mt})$ and least (174.33 Mt) in desert region (Table 3). Miscellaneous forest spread cover 40.7316 Mha has maximum soil organic carbon store $(6,469.80 \mathrm{Mt})$ while soil organic carbon store is least $(0.82 \mathrm{Mt})$ in Dipterocarpus macrocarpus forest with $0.0068 \mathrm{M} \mathrm{Ha}$ area. Among states Arunachal Pradesh has maximum soil organic carbon 
Table 1. Biomass and C in Indian Forests.

\begin{tabular}{ccccccc}
\hline Y ear & $\begin{array}{c}\text { Area } \\
\text { (M ha) }\end{array}$ & $\begin{array}{c}\text { V egetation } \\
\text { component }\end{array}$ & Biomass & \multicolumn{2}{c}{ Carbon } & Source \\
\cline { 5 - 6 } & & & M t & (t/ha) & \\
1984 & 63.9 & W & 2398.5 & 1085.16 & 16.98 & Manhas et.al (2006) \\
1985 & 64.2 & AG+BG & 4432.0 & 1994.40 & 31.07 & Dadhwal nayak (1993) \\
1986 & 64.0 & AG+BG & 8358.0 & 3761.10 & 58.77 & Ravindranath et.al.(1997) \\
1988 & 63.9 & AG+BG & 7742.4 & 3484.08 & 54.52 & Chhabra et al. (2002) \\
1993 & 64.0 & AG+BG & 8683.7 & 3907.67 & 61.06 & Chhabra et al. (2002) \\
1994 & 63.3 & AG+BG & 2395.4 & 1083.81 & 17.12 & Manhas et.al.(2006) \\
1995 & 63.9 & AG+BG & 4503.8 & 2020.71 & 31.72 & Lal and Singh (2000) \\
\hline
\end{tabular}

Table 2. Estimated rate of $\mathrm{C}$ flux in selected planted forests in India (Raizada et.al. 2003).

\begin{tabular}{lcccc}
\hline Tree species & $\begin{array}{c}\text { Area (000 ha) } \\
\text { (F SI,1999) }\end{array}$ & $\begin{array}{c}\text { Av.litter production } \\
\text { (t/ha/yr) }\end{array}$ & $\begin{array}{c}\text { C flux } \\
\text { (M t C/Y r) }\end{array}$ & $\begin{array}{c}\text { Total C flux in the } \\
\text { planted area (M t C/Y r) }\end{array}$ \\
\hline Eucalyptus spp. & 1360.91 & 4.50 & 2.03 & 27.5 \\
Tectona grandis & 1330.09 & 3.60 & 1.62 & 21.5 \\
Acacia auriculiformis & 564.67 & 3.03 & 1.36 & 7.7 \\
Pinus roxburghii & 318.54 & 4.94 & 2.22 & 7.1 \\
Dalbergia sissoo & 266.58 & 3.03 & 1.36 & 3.6 \\
Shorea robusta & 250.28 & 11.27 & 5.07 & 1.3 \\
Gmelina arborea & 148.01 & 2.17 & 0.97 & 1.4 \\
Casuarinas equisetifolia & 134.00 & 3.15 & 1.41 & 1.9 \\
Populous del toids & 47.48 & 3.71 & 1.66 & 0.8 \\
Bombax ceiba & 37.97 & 1.30 & 0.58 & 0.2 \\
\hline
\end{tabular}

Table 3. Soil organic carbon store in Indin natural forests (Jha et al., 2003).

\begin{tabular}{lccc}
\hline Region & F or est area* (M ha) & \multicolumn{2}{c}{ Soil organic carbon } \\
\cline { 3 - 4 } & & 16.71 & (\% of total all I ndia) \\
\hline North-east & 4.13 & 3650.53 & 37.19 \\
Himalayan region & 2.59 & 830.68 & 8.46 \\
Desert & 3.04 & 174.33 & 1.77 \\
Coastal & 6.25 & 498.84 & 5.08 \\
Alluvial plain & 29.71 & 1004.87 & 10.24 \\
Central peninsular region & 62.43 & 3656.70 & 37.25 \\
All India & & 9815.95 & \\
\hline
\end{tabular}

*As per 1994 forest stands

store $(1702.08 \mathrm{Mt})$ and least $(2.42 \mathrm{Mt})$ in Dadra and Nagar Haveli.

In undisturbed Himalayan foothill dipterocarp Sal (Shorea robusta) forests in Doon valley, Negi (1994) recorded $2.95 \mathrm{t} \mathrm{C} / \mathrm{ha} / \mathrm{yr}$ under natural forests, $6.7 \mathrm{t} \mathrm{C} / \mathrm{ha} / \mathrm{yr}$ in planted forest and $9.05 \mathrm{t} / \mathrm{C} / \mathrm{ha} / \mathrm{yr}$ for coppiced stand, while in another study (Negi and Chauhan 2002) the carbon sequestration potential for natural Sal forest has been estimated as $5.45 \mathrm{t} \mathrm{C} / \mathrm{ha} / \mathrm{yr}$. the old growth forest of $\mathrm{S}$. robusta and high altitude oak (Q uercus semicarpifolia) are demonstrated to sequester respectively $3.33 \mathrm{t} / \mathrm{ha} / \mathrm{yr}$ and $4.51 \mathrm{t} / \mathrm{ha} / \mathrm{yr} / \mathrm{C}$ from above ground component with major contribution $(75.8 \%$ for the former and $71 \%$ for the latter) from bole (Singh et al,.2006)

In young planted forests of teak (Tectona grandis) in Tarai area of Kumaun region of Indian central Himalaya, total system stores $46 \mathrm{t} / \mathrm{ha}$ (one year planted forest) to $113 \mathrm{t} / \mathrm{ha} \mathrm{C}$ (three year old planted forest). Soil pool contains $35.7 \mathrm{t} /$ ha to $43.9 \mathrm{t} / \mathrm{ha} \mathrm{C}$. total $\mathrm{C}$ return on forest floor through litter fall is recorded between $0.94 \mathrm{t} / \mathrm{ha} / \mathrm{yr}$ to $3.36 \mathrm{t} / \mathrm{ha} / \mathrm{yr}$ (Jha, 2005). Dey (2005) estimated average
C stock sequestered by planted forest of rubber ( $\mathrm{H}$ avea brazililensis) in north eastern India around $136 \mathrm{t} / \mathrm{ha}$ including $92.7 \mathrm{tC} / \mathrm{ha}$ of soil and $2.4 \mathrm{t} \mathrm{C} / \mathrm{ha}$ addition through litter fall and undergrowth vegetation. in Punjab among agroforestry models adapted by farmers, maximum $\mathrm{C}$ sequestration potential on annual basis has been estimated for planted forest of poplar (Populus del toids) as block $(4.42 \mathrm{t} / \mathrm{C} / \mathrm{ha})$ followed by poplar bund planting $(2.46 \mathrm{t} / \mathrm{C} / \mathrm{ha})$ and Eucalyptus (E. tereticornis) bund planting $(2.15 \mathrm{t} \mathrm{C} / \mathrm{ha})$.

Compared to ligneous species of old growth forest and industrial and rural plantations studies on $\mathrm{C}$ sequestration potential of bamboo species could not receive due attention of Indian academia and research. Recently Singh et al. (2006) recorded 1.48 time higher storage of C in Dendrocalamus strictus plantations at three years age (total carbon storage $96.35 \mathrm{t} / \mathrm{ha}$ above ground 74 percent and below ground 26 percent against Tectona grandis plantation (total carbon storage $65 \mathrm{t} / \mathrm{ha}$ ) at 30 years age (Jha et al., 2003), indicating plantation of bamboo evidently more viable option ecologically with regard to 
Table 4. Carbon sequestration (000 t) by planted forest of Rubber in North eastern India (Dey,2005).

\begin{tabular}{|c|c|c|c|c|c|}
\hline \multirow[t]{2}{*}{ State } & \multirow{2}{*}{$\begin{array}{c}\text { Rubber planted } \\
\text { for est ar ea in 2002- } \\
03 \text { (ha) }\end{array}$} & \multicolumn{2}{|c|}{$\begin{array}{c}\text { Carbon store } \\
\text { Rubber }\end{array}$} & \multirow[t]{2}{*}{$\begin{array}{c}\text { Annual } \mathrm{C} \text { addition from } \\
\text { under growth }\end{array}$} & \multirow[t]{2}{*}{ Total carbon } \\
\hline & & plant & soil & & \\
\hline Tripura & 28853 & 1762.9 & 1915.8 & 69.2 & 3747.9 \\
\hline Assam & 13208 & 807.0 & 919.2 & 31.7 & 1757.9 \\
\hline Meghalaya & 4586 & 280.2 & 451.2 & 11.0 & 742.4 \\
\hline Nagaland & 2087 & 127.5 & 225.4 & 5.0 & 357.9 \\
\hline Manipur & 1708 & 104.3 & 102.4 & 4.1 & 210.8 \\
\hline Mizoram & 696 & 42.5 & 62.4 & 1.7 & 106.6 \\
\hline Arunachal Pradesh & 372 & 22.7 & 58.4 & 8.9 & 90.0 \\
\hline Entire North East & 51510 & 3147.1 & 3734.8 & 131.6 & 7013.5 \\
\hline
\end{tabular}

carbon sequestration on account of many fold storage of $\mathrm{C}$ in its several rotations in the period (30 years) as considered for $\mathrm{T}$. grandis.

\section{Conclusion}

To stabilize and minimize the atmospheric concentration of GHGs, especially $\mathrm{CO}_{2}$, immediate reduction in anthropogenic ally accelerated contribution of Carbon at source is utmost important. Reducing use of fossil fuel and replacing them with alternative source of energy, increasing vegetation cover and minimizing use of nitrogen fertilizer. Of the steps undertaken in India concerning global climate change, exploring new and clean energy sources and conserving and sequestering C through conservation of old growth forest and generation of planted forests of improved genotypes, in vegetation and soil are much talked about. Pandey (2002) suggested integration of tools restoration ecology and conservation biology in management of multifunctional forests over landscape continuum as a vital option for climate change mitigation.

With regard to planted forests, especially for industrial raw materials, removal of whole tree biomass in short rotation which virtually releases stored soil and atmospheric $\mathrm{C}$ quickly is not a desirable long term means of $\mathrm{C}$ storage and ecosystem sustainability. Maintaining proper density is vital for both natural and planted forests. Application need to be studied for $\mathrm{C}$ sequestration potential and the best performing ones be given priority in $\mathrm{C}$ forests, bamboo based agro forests and bamboo forestry in wastelands. The $\mathrm{C}$ sequestration by the forest vegetation can further be enhanced using a mix option viz (i) Better management of the existing dense forests maintained for biodiversity conservation, watershed value and ecological balance (ii)Improving regeneration of open and degrade forests through human assistance favorably (iii) Multispecies reforestation on non forest and forest wastelands and iv)Adopting farm forestry in marginal arable lands and crop field's boundaries, creation of large scale C sinks through people's forestry. e.g smiriti van (memorial forest), ethno forests, bio carbon oriented watershed forestry and urban forest etc. joint forest management and business houses commercial forests initiative may widen the scope of $\mathrm{C}$ forestry.

Suitable land for such public based $\mathrm{C}$ forestry activities may be provided on need basis by the Forest and revenue departments following partnership approach. Location specific sustainable silvicultural practices for multiple use forestry, long term $\mathrm{C}$ storage in soil and improved $\mathrm{C}$ sequestration potential are yet a challenge. Since the degraded lands would be the major areas for $\mathrm{C}$ forestry. Restoration ecological science research need be widened further with bio social perspective. The wood utilization technology research needs to widen innovative means for non $\mathrm{CO}_{2}$ or low $\mathrm{CO}_{2}$ emitting uses of harvested wood and adding value to harvested wood which could lock carbon for a longer period, thus strengthen ex-situ $\mathrm{C}$ retention. In regard to $\mathrm{C}$ release through wood fuel burning, integrating use of efficient cooking devices, biogas, LPG and kerosene can reduce the fuel wood consumption and ultimately the $\mathrm{C}$ release in atmosphere besides indoor pollution.

\section{REFERENCES}

Bouwman., A.F. (1990). Soils and the green house effect. Proc. Intl. Conf. on soils and the green house effect.John Wiley and sons, New York,USA.

Callaway, J.M. and McCarl, B. (1996). The economic consequences of substituting carbon payments for crop subsidies in US agriculture. Envron. Resource Econ., 7: 15-43.

Chaturvedi,A.N. (1994). Sequestration of atmospheric carbon in Indian forest. Ambio., 23: 460-461.

Chhabra,A., Parlia, S. and Dadhwal, V. K. (2002). Growing stock based forest biomass estimate of India. Biomass and Bioenergy, 22:187-194.

Dey, S. K. (2005). A preliminary estimation of carbon stock sequestered through rubber (H avea brasiliensis) plantation in North-Eastern region of india. Indian Forester, 131 (11): $1429-1436$

Jha, K.K. (2005). Storage and flux of organic carbon in tectona grandis plantation of moist deciduous forest. Indian F orester, 131 (5) : 647-659.

Jha, M.N., Gupta, M.K., Saxena, A. and Kumar, R. (2003). Soil organic carbon store in different forest of India. Indian Forester, 129 (6):714-724.

Katila, A. M. and Puustjarvi, E. (2004). Markets for forest 
environment services: reality and potential. U nasylva, 219 (55) : 53-58.

Leemans,R. and B. Eickhout (2004). Another reason for concern: regional and global impacts on ecosystems or different level of climate change. Global Environ change., 14: 219-228.

Manhas, R.K, Negi, J.D.S., Kumar, R. and Chauhan, P.S. (2006). Temporal assessement of growing stock biomass and carbon stock of Indian forests. Climate C hange, 74:191-221.

Negi, J.D.S.(1994). Biological productivity and cycling of nutrients in managed and manmade ecosystems.Ph.d Thesis, Garwhal University, Srinagar.pp.161.

Negi, J.D.S. and P.S. Chauhan (2002). Green house gases mitigation potential by Sal (Shor ea robusta Gaertn.f.) forest in Doon valley. Indian Forester, 128 (7):771-778.

Pandey, D.N.(2002). Global climate change and carbon management in multifunctional forest. Curr.Sci., 83 (5): 593602.
Raizada,A., A.K. Parandiyal and B.N.Ghosh (2003). Estimation of carbon flux through litter fall in forest plantation of India. Indian F orester, 129 (7) : 881-894.

Ravindranath,N.H. and J.A. Sathaye (2002). Climate change and developing countries. Advances in global change research, kluwer Academic publishers, Dordrecht.

Singh,V.A. Tiwari, M.Gupta and J.Ram (2006). The pre logged stocks of carbon in Shorea robusta and Quercus semicarpifolia forests of Uttaranchal and their $\mathrm{C}$ sequestration rates - a tradable NTFP.Int.J.F or U suj M gmt.7(1):1-5

Sombroek, W.G., Nachtergaele, F.O. and A. Hebel (1993). Amounts, dynamics and sequestering of carbon in tropical and subtropical soils. Ambio., 22 (7):417-426.

Stavins, R. N. (1999). The costs of carbon sequestration: a revealed preference approach. Ann. Econ. Rev., 89: 9941009 